J. Perinat. Med. 16 (1988) 467

\section{Intrauterine death of a single fetus in twin pregnancies}

\author{
Jens Wessel ${ }^{1}$ and Karin Schmidt-Gollwitzer ${ }^{2}$ \\ ${ }^{1}$ Free University of Berlin, University Clinic Rudolf Virchow, Gynaecological Clinic \\ Charlottenburg, Berlin, West Germany \\ ${ }^{2} \mathrm{Fa}$. Schering AG, Berlin, West Germany
}

\section{Introduction}

The intrauterine death of a single fetus in twin pregnancies is a rare event in obstetrics. Apart from individual case reports, the literature does also contain reports on larger study populations $[1,6,8,11]$. Both the further management of the pregnancy taking into account the risk for the surviving twin and the mother and the procedure to be employed at delivery are of particular clinical interest. Special account must be taken of the causes which led to the intrauterine demise and the neonatal period of the surviving twin must be closely monitored. We report on our experience of this pathological course of pregnancy over the last six years.

\section{Results}

In the period 1982-1987, our hospital encountered nine twin pregnancies in which one of the twins was dead at the time of delivery. The incidence is $0.10 \%$ referred to all births $(\mathrm{n}=8.808)$ in the six-year observation period, but $5.42 \%$ referred to all twin births $(\mathrm{n}=186)$. The maternal age was 33.1 years (age range $26-41$ years). Six women were para 1, two were para 2 and one was para 3 . The average age of the pregnancy at the time of delivery was 33.4 weeks $(25-38$ weeks) (table I). An autopsy was performed on all the dead twins and the placentas were examined histologically.

The birth weight of the surviving twin (table I) was less than $1,000 \mathrm{~g}$ in two cases, between 1,500 and $2,500 \mathrm{~g}$ in five and above $2,500 \mathrm{~g}$ in two cases.

Course of the neonatal period: Cases 2, 5 and 6 did not need to be transferred to the Department for

\section{Curriculum vitae}

JeNS WeSSEL, M.D., was born 1953 in Lüneburg, Germany. He studied biology and social affairs 1973-1979 and medicine 1979-1985. Until 1986 he was research associate at the Forensic Science Institute of the Free University of Berlin. Doctoral thesis in 1986. Since 1986 he has been research associate at

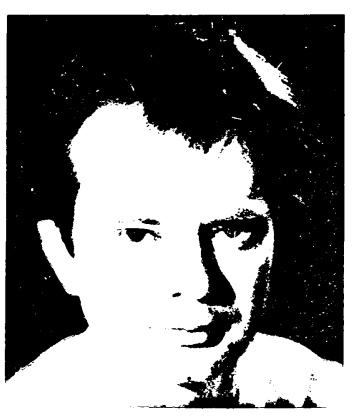
the Universitäts-Frauenklinik Charlottenburg at the Free University of Berlin.

Neonatology, and the neonatal period was normal apart from hyperbilirubinaemia in Case No. 5. The other six newborns $(<35$ th week of pregnancy) all required treatment and the neonatal period differed in each case (table I). Of the twins born live, one died (Case No. 9).

Apart from the extreme immaturity at birth (25th week of pregnancy), the cause of death was anemic shock secondary to terminal shunt reversal in fetofetal transfusion (table I).

The twins who died in utero were mostly hypotrophic (Case Nos. 2, 3, 4, 8 and 9), although 2 were eutrophic (Nos. 1 and 7).

Apart from Case No. 6 (fetus papyraceus), the reasons for the big differences in the weight of the twins which died in utero were the different periods of gestation and, in particular shifts of weight between the two twin partners in fetofetal transfusion. 


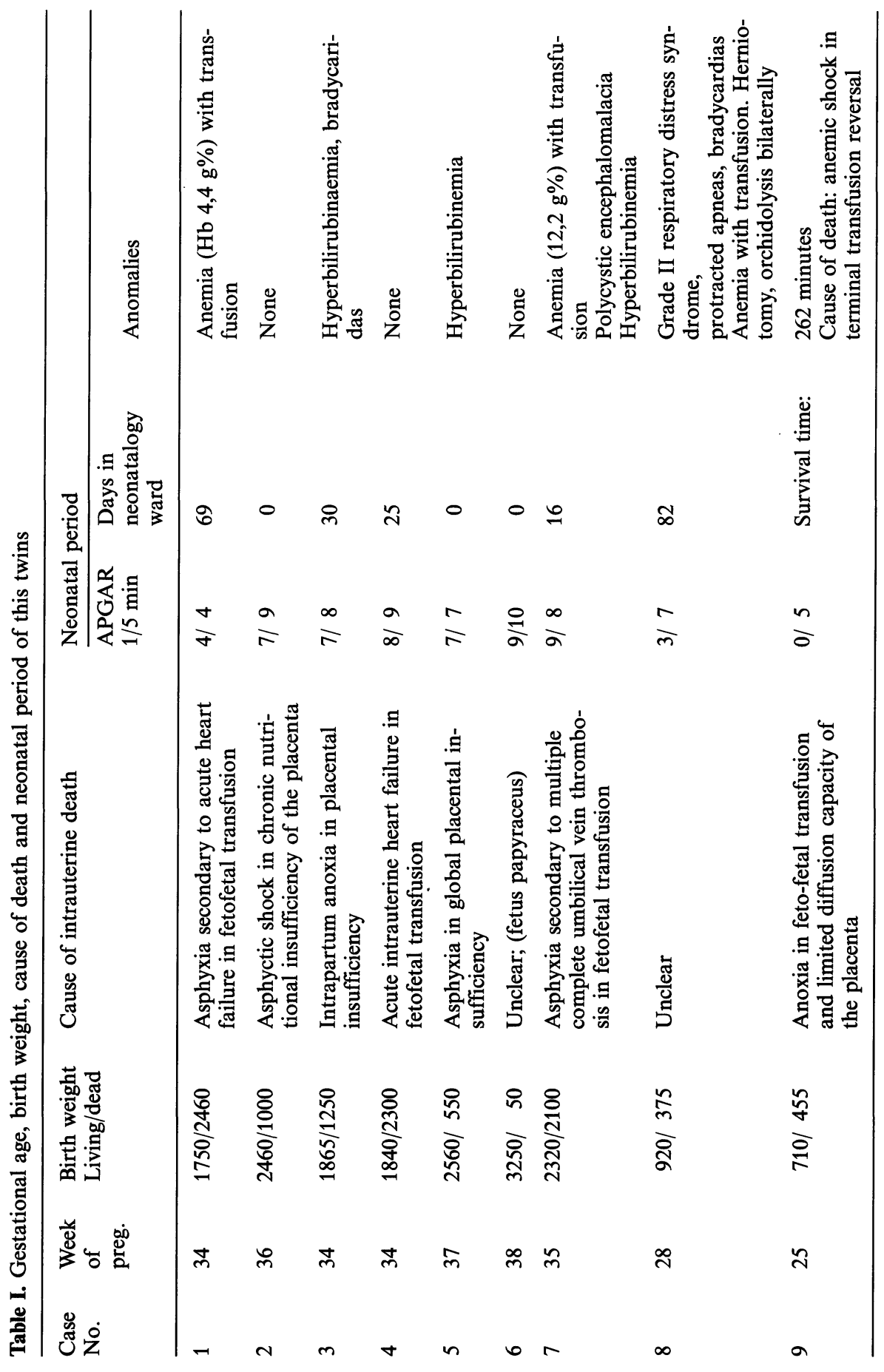


The cause of intrauterine death was placental insufficiency in three cases and a fetofetal transfusion syndrome in another three. Heart failure in fetofetal transfusion was the cause in Case No. 4, while the cause of death remained unclear in Case Nos. 6 and 8.

Grade I maceration was seen in Case No. 1, Grade II in numbers 2 and 7, and Grade III in numbers 4, 5 and 8. Two fetuses displayed no signs of maceration, one (Case No. 3) under the picture of acute maternal pre-eclampsia, the other (Case No.9) after unsuccessful tocolysis in premature labor pains in the 25th week of pregnacy (fetofetal transfusion had been suspected since the 22nd week on the basis of the echographic finding of a difference in growth).

No malformations were observed in the twins which died in utero.

\section{Method of delivery}

Only one delivery was spontaneous. The other eight $(89 \%)$ were by caesarean section- in four cases because of breech presentation of one or both twins. In two of these (Nos. 2 and 5), the surviving twin led in the breech position and was followed by the dead fetus, also in the breech position. The mothers in these two cases were para 1. In the other two cases, the dead fetuses led in the breech presentation, followed in Case No. 1 by the surviving twin in the transverse position and in Case No. 4 (para 1) by the much smaller survivor in the vertex presentation. The reason for caesarean section section in Case No. 3 was preeclampsia with threatened asphyxia of the survivor, and in Case Nos. 6 and 8 profuse vaginal bleeding with (suspected) premature detachment of the placenta. The reason in Case No. 9 was an urgent desire for children over many years; in the presence of therapy-resistant labor pains in the 25 th week, the mother requested the most promising method of delivery for the still surviving twin (table II).

The sex ratio of all the newborns was ten male to seven female (the sex was not recorded in the case of the fetus papyraceus, which corresponded to the 17 th week of pregnancy), while that of the fetuses which died in utero was three male to five female and that of the surviving partners was seven male to two female. In four cases the leading twin died in utero.

Table II. Fetal presentation and method of delivery with indications

\begin{tabular}{|c|c|c|c|c|}
\hline \multirow{2}{*}{$\begin{array}{l}\text { Case } \\
\text { No. }\end{array}$} & \multicolumn{2}{|l|}{ Presentation } & \multirow{2}{*}{$\begin{array}{l}\text { Method } \\
\text { of delivery }\end{array}$} & \multirow[t]{2}{*}{ Indication } \\
\hline & I & II & & \\
\hline 1 & Breech $(+)$ & Transverse & Caesarean & Positional anomaly \\
\hline 2 & Breech & Breech $(+)$ & Caesarean & Positional anomaly \\
\hline 3 & Vertex & Breech $(+)$ & Caesarean & $\begin{array}{l}\text { Pre-eclampsia } \\
\text { Threatened asphyxia of first twin }\end{array}$ \\
\hline 4 & Breech $(+)$ & Vertex & Caesarean & Positional anomaly \\
\hline 5 & Breech & Breech $(+)$ & Caesarean & Positional anomaly \\
\hline 6 & Vertex & $\begin{array}{l}\text { (Fet. } \\
\text { pap.) }(+)\end{array}$ & Caesarean & $\begin{array}{l}\text { Suspected premature detachement of the } \\
\text { placenta }\end{array}$ \\
\hline 7 & Vertex & Vertex $(+)$ & Spontaneous & - \\
\hline 8 & Vertex $(+)$ & Vertex & Caesarean & $\begin{array}{l}\text { Threatened asphyxia } \\
\text { Deep placenta, detachment of margins }\end{array}$ \\
\hline 9 & Vertex & Vertex $(+)$ & Caesarean & $\begin{array}{l}\text { Therapy-resistant premature labor } \\
\text { Mother requested optimal method of delivery } \\
\text { for surviving twin }\end{array}$ \\
\hline
\end{tabular}

$(+)=$ died in utero 
Table III shows the nature of the placental membrane: there were five cases of monochorionicdiamniotic placenta and three of dichorionicdiamniotic placenta (no relevant information is available for the fetus papyraceus). In four cases, appropriate shunt communications meant that the morpho-anatomical conditions were available for the presence of a fetofetal transfusion syndrome (Case Nos. 1, 4, 7 and 9). Other and above this, Case No. 9 also exhibited the morphological findings in at least one part of the placenta for the presence of nidation damage (marginal, eccentric, extremely eccentric insertion of the umbilical cord, velamentous insertion, aplasia of an umbilical artery).
As was only to be expected, symptoms of gestosis were the main abnormalities in the course of the pregnancies (table IV).

The fact that intrauterine death had occured some time ago was known at the time of delivery in only three cases: in Case No. 5, fetal death (according to the autopsy at the gestational age of $29 / 30$ weeks) was diagnosed in the 34th week of pregnancy and the mother was then admitted to hospital for continuous observation; in Case No. 8, fetal death of the first twin occured in the 24th week of pregnancy after several days in hospital.

Table III. Main placental findings with special reference to cases with fetofetal transfusion

\begin{tabular}{|c|c|c|}
\hline $\begin{array}{l}\text { Case } \\
\text { No. }\end{array}$ & $\begin{array}{l}\text { Type of } \\
\text { placenta }\end{array}$ & $\begin{array}{l}\text { Shunt relation- } \\
\text { ship in fetofetal } \\
\text { transfusion }\end{array}$ \\
\hline 1 & $\begin{array}{l}\text { monochorionic } \\
\text { diamniotic }\end{array}$ & $\begin{array}{l}\text { I acceptor }(+) \\
\text { II donor }\end{array}$ \\
\hline 2 & $\begin{array}{l}\text { monochorionic } \\
\text { diamniotic }\end{array}$ & - \\
\hline 3 & $\begin{array}{l}\text { dichorionic } \\
\text { diamniotic }\end{array}$ & - \\
\hline 4 & $\begin{array}{l}\text { monochorionic } \\
\text { diamniotic }\end{array}$ & $\begin{array}{l}\text { I acceptor }(+) \\
\text { II donor }\end{array}$ \\
\hline 5 & $\begin{array}{l}\text { dichorionic } \\
\text { diamniotic }\end{array}$ & - \\
\hline 6 & - & - \\
\hline 7 & $\begin{array}{l}\text { monochorionic } \\
\text { diamniotic }\end{array}$ & $\begin{array}{l}\text { I donor } \\
\text { II acceptor }(+)\end{array}$ \\
\hline 8 & $\begin{array}{l}\text { dichorionic } \\
\text { diamniotic }\end{array}$ & - \\
\hline 9 & $\begin{array}{l}\text { monochorionic } \\
\text { diamniotic }\end{array}$ & $\begin{array}{l}\text { I acceptor } \\
\text { II donor (+) }\end{array}$ \\
\hline
\end{tabular}

Autopsy or clinical signs in the shunt partners

Acceptor eutrophic, pronounced plethora Donor hypotrophic $(-710 \mathrm{~g})$, considerable anemia

$-$

Acceptor with substantial overweight $(+460 \mathrm{~g})$, plethora

$-$

Both eutrophic, donor with anemia

Presumed shunt reversal in fresh thrombosis of the serpinginous upper plate varices of II in atypical plethora of the placental part of I

I Cardiomegaly, eutrophic; II hypotrophic

1) Chronic fetofetal transfusion to I

2) Progressive intrauterine hypoxia II via placental vascular anastomosis after IFD* and cessation of the fetal circulation

3) Terminal fetofetal transfusion change with reversal of the donor-acceptor relationship leading to development of severe anemia I (now donor) and massive plethora of the already dead second twin (now acceptor)

* IFD = intrauterine fetal death

$(+)=$ died in utero 
Table IV. Events during the course of pregnancy

\begin{tabular}{ll}
\hline Case & 31st week: \\
No. 1 & Pre-eclampsia, hydramnios \\
Case & 26th week: \\
No. 3 & Pre-eclampsia \\
& 32nd week: \\
& Pre-eclampsia \\
& 33rd/34th week: \\
& Pre-eclampsia \\
Case & 29th/31st week: \\
No. 4 & Premature labour (oral tocolysis) \\
Case & 14th week: \\
No. 8 & Imminent abortion \\
& Urinary tract infection \\
& 23rd week: \\
& Pre-eclampsia \\
Case & 22nd week: \\
No. 9 & Pyelonephritis with urinary \\
& stasis on right \\
& 23rd week: \\
& Percutaneous nephrostomy right \\
& 24th week: \\
& Premature labour (i. v. tocolysis, unsuccess- \\
& ful) \\
\hline
\end{tabular}

A gestationel age fo 28 weeks was reached under further hospitalized observation with the occurence of severe vaginal bleeding and signs of asphyxia in the cardiotocogram (CTG); in the other Case (No. 6, fetus papyraceus), the death of the fetus (gestational age corresponding to the 17th week) was diagnosed in the 20th week of pregnancy, but the mother was not admitted to hospital for observation. In four cases, the acute diagnosis of intrauterine death of one of the fetuses demanded curtailment of the period of hospitalized observation because of prepathological CTG signs from the surviving twin (Nos. 4 and 7), advanced gestational age (Nos. 2, 4 and 7) or unstoppable labor pains (Nos. 1 and 4).

No complications secondary to the intrauterine fetal death were observed as regards maternal morbidity or the puerperium.

\section{Discussion}

It is a well-known fact that twin pregnancies are associated with more risks than single pregnancies. The mortality rate for twins is $3-4$ times higher than for single newborns and the morbidity rate is also increased, in particular because of the high rate of premature births. The second twin is at particular risk in this respect. The rate of intrauterine deaths is also about $2-3$ times higher than that for single pregnancies [8]. The intrauterine demise of a twin raises diverse questions concerning the risk to the surviving twin and the mother and the method of delivery. The occurence of such an event is rare, but the possibility of an increase resulting from an above-average rate of twin pregnancies in association with stimulation ovulation induction or in vitro fertilization programs should be kept in mind.

The incidence of $0.10 \%$ in our study population referred to all births is compatible with the figures reported by LUMME and SAARIKOVSKI $(0.03 \%)$ [8] and LITSCHGI and STUCKI (0.07\%) [6]. Referred to all twin births in the observation period, we recorded an incidence of $5.4 \%$ compared to values of $2.2 \%$ [8] and $6.8 \%$ [6].

At 33.1 years, the average maternal age was distinctly higher than in the other studies (e.g. 28 years in the study by LUMME and SAARIKOVSKI).

In agreement with other authors, the results of our study show that the intrauterine death of a twin in itself does not expose the mother to any increased risk. However, the number of mothers in our study who were observed for a prolonged period after diagnosis of the intrauterine death was relatively small $(n=3$, of whom 2 were hospitalized). Among others, SKELLY draws attention to the risk of consumptive coagulopathy (with a decrease of fibrinogen, increase of break-down products of fibrinogen and reduced platelet count) which can be induced by thromboplastin absorption from the tissue of the dead fetus or from the placenta [13]. This clotting disorder usually occurs a few weeks after the death: PRITCHARD [10] reported an incidence of $25 \%$ in the case of dead fetuses in single pregnancies retained for more than 4-5 weeks. This risk appears to be much lower in the case of a single fetal death in a twin pregnancy [13]. According to ROMERO et al., the maternal clotting status should nevertheless be closely monitored and, if necessary, heparinization performed [12]. We performed prophylactic lowdose heparinization in one of our patients.

Of the surviving twins in utero, one died after delivery $(11.1 \%)$; the gestational age in this case was 25 weeks, the lowest in our study. Other authors report mortality rates of between $4.1 \%$ [8] and $23.1 \%$ [6]. 
Three of the children in our study exhibited an APGAR score of $\leq 4$ at 1 minute. In agreement with RIEHN, it can be assumed that there is no association between the vitality of the surviving newborn and the length of time between the intrauterine death of the other twin and the delivery [11]. In analogy to single pregnancies or to twin pregnancies which are not complicated by the intrauterine death of one of the twins, morbidity depends mainly on the gestational age achieved; at an average of 33.4 weeks, this was comparatively low in our study.

There was no need to transfer the surviving partner to the neonatology deparment in cases in which a gestational age of at least 35 weeks had been achieved.

At $89 \%$, the high rate of caesarean section as the method of delivery was striking. Other study groups report rates of between 9\% [11] and 93\% [1]. The incidence of caesarean sections is largely determined by the obstetrician's attitude to the delivery of breech presentations [8]: in our study population, this positional anomaly was the sole indication in four cases. It was also the sole indication for caesarean section in half of the cases reported by D'ALTON, while LITSCHGI and STUCKI performed caesarean section in only one case of breech presentation. At the same time, the proportion of women with a longer period of hospitalized supervision after diagnosis of the intrauterine fetal death was considerably larger in the studies with a low incidence of caesarean section. The greater readiness to deliver by caesarean section is more understandable in cases in which intrauterine fetal death is diagnosed acutely and other risk factors such as profuse vaginal bleeding are present at the same time. Neither the surviving nor the dead twins displayed any congenital malformations in our study. LITSCHGI and STUCKI [6] reported just one case of hypospadia (in a study population of 13 twin pairs), RIEHN [11] observed one case of hydrocephaly and one pair of twins with thanatophoric dwarfism out of 11 pairs of twins, while LUMME and SAARIKOVSKI [8] reported a total of 6 (including multiple) malformations out of 24 pairs of twins.

The attending pediatricians interpreted the case of polycystic encephalomalacia (in the donor) as the consequence of severe intrauterine hypoxia secondary to fetofetal transfusion. An arterial occlusion due either to disseminated intravascular clotting in fetofetal exchange of thromboplastic ma- terial of the dead fetus through vascular shunts or to embolisation of infarcted, necrotic bits of tissue is regarded as the cause of this encephalomalacia in surviving partners of monochorionic twins $[3,8]$.

The incidence of fetus papyraceus with delivery of the living twin partner is reported as $1: 12,000$ births or 1:184 twin pregnancies [9]. Most of the fetuses die in the second trimester $[4,7]$. The condition arises as a result of compression of the mummified fetus between the amnion and the uterine wall or the fetal partner over a sufficiently long period, which explains why the conditions does not occur in single pregnancies or when death of a twin occurs at a later time (third trimester). A fetus papyraceus can develop in the case of both monochorionic and dichorionic placentas [7] as well as in the fetofetal transfusion syndrome [5].

The incidence of monochorionic placentas in our study is compatible with that reported by other investigators: 5 of 9 cases, 4 of them with a fetofetal transfusion syndrome. The acceptor died in utero in 3 cases, the donor in one. KLoos and VOGEL make a distinction between a chronic fetofetal transfusion syndrome with early embryonal manifestation (development of a holoacadius) and a late-embryonal/early-fetal manifestation after formation of the vascular system of both twins. The latter generally leads to hypotrophy and anemia of the donor and to cardiomegaly and plethora of the acceptor. The date of manifestation for the subchronic form is assumed to be a few weeks before term; the diagnosis is made partly on the basis of considerable anaemia of the donor without any distinct difference in the weights of the twins. In the acute form, the donor can suffer an acute hemorrhagic shock and the acceptor an acute load on the cardiac volume as a result of a sudden transfer of blood. The development of a fetus papyraceus in the fetofetal transfusion syndrome is also possible [5].

The transfusion syndromes reported here were chronic in three cases (Numbers 1, 4, and 9) and subchronic in one (No. 7). A blood transfusion was required in the neonatal period in the two chronic cases in which the donor survived (one of them with the remarkably low initial $\mathrm{Hb}$ value of $4.4 \mathrm{~g} \%$ ). Case Numbers 7 and 9 suffered a reversal of the donor-acceptor relationship in terminal shunt reversal, presumably shortly before delivery.

According to published experience, the procedure and timing for the termination of a pregnancy 
with a surviving twin are determined primarily by the state of maturity of this child. The type of placenta should also be taken into account: if a dizygotic situation is definitely present (ultrasound demonstration of two placentas, different sexes), it can generally be assumed that there is no increased fetal risk, and the spontaneous onset of labour can be awaited under monitoring of the fetal and maternal parameters. If a monochorionic situation cannot be ruled out, there is an increased risk to the surviving twin through shunt communications, which can lead to DIC induced death or organ damage $[2,3]$.

The following general guidelines are proposed in the event of the intrauterine death of a fetus in a twin pregnancy:

There is no directly associated increased risk to the mother; the relevant parameters should be monitored continuously to detect any disturbances in the clotting system. The intrauterine death of one twin is not an absolute indication for termination of the pregnancy of the surviving partner. Thorough CTG and ultrasound monitoring should be performed in order to detect any risk factors which, in the case of a monochorionic placenta, might develop for the survivor as a result of a shunt reversal in a fetofetal transfusion syndrome. This is also the only way in which the condition of the surviving twin can be monitored, and it is this condition which - apart from complications (hemorrhage) which might occur at any time - determines the time and method of delivery. An attempt should always be made to achieve pulmonary maturity through the attainment of an appropriate gestational age or by induction. Close supervision of the condition of the mother and surviving child is essential and the mother should be admitted to hospital for this purpose. Ideally, it should be possible as a result to reduce the incidence of caesarean sections to that for uncomplicated twin pregnancies.

\begin{abstract}
The paper reports on nine twin pregnancies in the years 1982-1987 with the intrauterine death of a single fetus. The incidence of $0.10 \%$ is consistant with that reported in other comparable studies.

Evaluation of the causes of death shows a preponderance of asphyxia. A fetofetal transfusion syndrome occurred in 4 cases. Eight of the pregnancies were terminated by caesarean section. One of the surviving children died in
\end{abstract}

the neonatal period. The course of the neonatal period in the other babies was determined mainly by the state of maturity. No increased maternal morbidity was observed.

On the basis of this and other experience described in the literature, some general guidelines are proposed for the management of the further pregnancy and delivery in such high-risk cases.

Keywords: Intrauterine death of one twin, mode of delivery, neonatal morbidity, placentation, twin pregnancy.

\section{Zusammenfassung}

\section{Intrauteriner Fruchttod eines Feten bei Zwillingsschwan- gerschaften}

Der intrauterine Tod eines Feten bei Zwillingsschwangerschaften ist ein seltenes Ereignis in der Geburtshilfe. Dabei gilt das besondere klinische Interesse zum einen der weiteren Führung der Schwangerschaft unter Einbeziehung des Risikos für den überlebenden Feten wie auch der Mutter, zum anderen dem Entbindungsmodus für den abgestorbenen Feten.

Zwischen 1982 und 1987 wurden in unserer Klinik neun Zwillingsschwangerschaften aufgenommen, bei denen jeweils ein Zwilling zum Zeitpunkt der Entbindung abgestorben war (entsprechend einer Inzidenz von $0,10 \%$ in Bezug auf alle Geburten bzw. 5,42\% in Bezug auf Zwillingsgeburten). Das durchschnittliche mütterliche Alter betrug 33,1 Jahre. Das durchschnittliche Schwangerschaftsalter bei Entbindung lag bei 33,4 Wochen.
Alle toten Zwillingsfeten wurden obduziert sowie sämtliche Plazenten histologisch untersucht.

In zwei Fällen lag das Geburtsgewicht des überlebenden Zwillings unter $1000 \mathrm{~g}$, in fünf Fällen zwischen $1500 \mathrm{~g}$ und $2500 \mathrm{~g}$ und in zwei Fällen über $2500 \mathrm{~g}$.

Drei Neugeborene brauchten nicht auf eine neonatologische Intensivstation verlegt $\mathrm{zu}$ werden. Die anderen sechs Neugeborenen (unter 35 Schwangerschaftswochen) benötigten unterschiedlich lange eine neonatologische Intensivüberwachung. Einer der lebendgeborenen Zwillinge starb. In drei Fällen war die intrauterine Todesursache eine Plazentainsuffizienz, bei weiteren drei ein feto-fetales Transfusionssyndrom, in einem Fall Herzversagen bei feto-fetaler Transfusion ind in zwei Fällen blieb die Todesursache ungeklärt.

Bei den intrauterin abgestorbenen Zwillingen wurden keine Mißbildungen beobachtet. 
Eine Entbindung verlief spontan, während in acht Fällen $(89 \%)$ eine Sectio caes area notwendig war.

Die Geschlechtsverteilung aller Neugeborenen betrug zehn Jungen gegenüber sieben Mädchen, bei den in utero verstorbenen Feten drei Jungen zu fünf Mädchen und bei den jeweils überlebenden Zwillingen sieben Jungen zu zwei Mädchen. In vier Fällen starb der führende Zwilling intrauterin $\mathrm{ab}$.

Zum Aufbau der Plazenta: in fünf Fällen handelte es sich um eine monochoriatisch-diamniotische Plazenta und in drei Fällen um eine dichoriatisch-diamniotische Plazenta. Bei vier Fällen ließen sich Verbindungen im Sinne von Shunts nachweisen als morphologisch-anatomische Voraussetzung für ein feto-fetales Transfusionssyndrom.

Wie erwartet, waren Gestosesymptome die häufigsten Komplikationen bei den Schwangerschaftsverläufen.

Nur in drei Fällen war bekannt, daß der intrauterine Tod schon einige Zeit vor der Entbindung erfolgte.

Hinsichtlich der mütterlichen Morbidität und des Wochenbetts war die Komplikationsrate nach einem intrauterinen fetalen Tod nicht erhöht.

Die Mortalitätsrate liegt bei Zwillingen 3-4fach höher als bei Einlingen. Auch die Morbidität ist erhöht, speziell wegen der häufigeren Frühgeburten. Dabei hat vor allem der zweite Zwilling ein höheres Risiko. Ein intrauteriner Tod ereignet sich 3-4mal häufiger als bei Einzelschwangerschaften [8].

Die in unserer Untersuchungsgruppe gefundene Inzidenz von $0,10 \%$ ist mit der anderer Autoren vergleichbar.

Mit 33,1 Jahren war das durchschnittliche mütterliche Alter geringfügig höher als in anderen Studien.

Von den lebendgeborenen Zwillingen starb einer post partum $(11,1 \%)$; er hatte mit 25 Schwangerschaftswochen das niedrigste Gestationsalter in unserem Kollektiv. Zwischen der Vitalität des überlebenden Neugeborenen und der Dauer zwischen intrauterinem Tod des anderen Zwillings und der Entbindung gibt es keinen Zusammenhang.

Auffallend ist die mit $89 \%$ sehr hohe Sektiorate. Das Verhalten des Geburtshelfers bei Steißlagen bestimmt in weitem Maße die Inzidenz von Kaiserschnitten. In unserem Kollektiv war in vier Fällen die Steißlage die alleinige Sektioindikation. Eine größere Bereitschaft zur Sektio ist in den Fällen verständlich, wo ein intrauterines fetales Absterben akut diagnostiziert wird und gleichzeitig andere Symptome wie starke vaginale Blutungen auftreten. Weder die überlebenden noch die abgestorbenen Zwillinge zeigten irgendeine angeborene Mißbildung.

Die Inzidenz von monochoriatrischen Plazenten in unserer Studie ist vergleichbar mit den Zahlen anderer Autoren: bei neun Fällen traten sie fünfmal auf, davon lag in vier Fällen ein feto-fetales Transfusionssyndrom vor. Dabei kam es beim Empfänger in drei Fällen zum intrauterinen Absterben, beim Spender in einem Fall.

Bei 3 Fällen lag ein chronisches, in einem Fall ein subchronisches Transfusionssyndrom vor. In den zwei Fällen mit chronischem Transfusionssyndrom, wo der Spender überlebte, waren Bluttransfusionen erforderlich (in einem Fall lag mit 4,4 g\% ein initial sehr niedriger $\mathrm{Hb}$ Wert vor).

In Übereinstimmung mit den publizierten Erfahrungen sind die Form und der Zeitpunkt für die Beendigung von Schwangerschaften mit einem lebenden Zwilling in erster Linie durch den Reifestatus dieses Kindes bestimmt. Auch der Plazentamorphologie sollte Rechnung getragen werden: wenn definitiv eine dizygote Form vorliegt (sonographischer Nachweis von zwei Plazenten, unterschiedliches Geschlecht), kann man davon ausgehen, daß das fetale Risiko nicht erhöht ist. Unter Überwachung fetaler und maternaler Parameter kann ein spontanes Einsetzen der Wehentätigkeit abgewartet werden. Ist eine monochoriatische Form nicht auszuschlieBen, besteht ein erhöhtes Risiko für den überlebenden Zwilling durch Shuntverbindungen, über die eine DIC mit nachfolgendem Tod oder Organschädigung induziert werden kann.

Wir schlagen folgende allgemeine Richtlinien im Falle des intrauterinen Absterben eines Feten bei Zwillingsschwangerschaften vor:

Es gibt kein mit dieser Situation direkt assoziiertes erhöhtes Risiko für die Mutter; die wichtigen Gerinnungsparameter sollten kontinuierlich überwacht werden, um Störungen im Gerinnungssystem zu erfassen. Das intrauterine Absterben eines Zwillings ist keine absolute Indikation zur Beendigung der Schwangerschaft. Jedoch sollte eine cardiotokographische und sonographische Überwachung erfolgen, um Risikofaktoren zu erkennen, die im Falle einer monochoriatischen Plazenta das Risiko für den überlebenden Zwilling in Form einer Shuntumkehr bei feto-fetalem Transfusionssyndrom beinhalten. Cardiotokographie und Sonographie sind die entscheidenden Überwachungsmethoden beim überlebenden Zwillingsfeten, und sie bestimmen Form und Zeitpunkt der Entbindung, außer es kommt zu Komplikationen wie z. B. Blutungen, die jederzeit auftreten können. Man sollte immer versuchen, eine Lungenreife zu erzielen, entweder durch Abwarten bis zum adäquaten Gestationsalter oder durch Induktion. Eine engmaschige Überwachung von Mutter und überlebendem Zwilling ist essentiell. Daher sollte eine Einweisung in die Klinik erfolgen. Im Idealfall sollte es möglich sein, die Inzidenz von Sectiones die der bei unkomplizierten Zwillingsschwangerschaften anzunähern.

Schlüsselwörter: Entbindungsmodus, intrauteriner Tod eines Zwillings, neonatale Morbidität, Plazentation, Zwillingschwangerschaft. 


\section{Résumé}

\section{Mort intra-utérine d'un des fottus au cours des grossesses gémellaires}

La mort intra-utérine d'un fœtus au cours des grossesses gémellaires est rare en obstétrique. La prise en charge ultérieure de la grossesse en prenant en compte le risque pourle jumeau survivant et pour la mère ainsi que la conduite à tenir pour l'accouchement sont d'un intérêt clinique particulier.

Pendant la période 1982-1987, il y a eu dans notre hopital 9 grossesses gémellaires au cours desquelles un des jumeaux était mort au moment de l'accouchement (incidence de $0,1 \%$ de toutes les naissances, mais incidence de $5,42 \%$ de toutes les naissances gémellaires). L'âge maternel est de 33,1 ans. L'âge gestationnel moyen au moment de l'accouchement est de 33,4 semaines.

Une autopsie a été effectuée sur tous les jumeaux morts et les placentas ont été examinés en histologie.

Le poids de naissance du jumeau survivant était inférieur à $1000 \mathrm{~g}$ dans deux cas, compris entre 1500 et $2500 \mathrm{~g}$ dans 5 cats supérieur à $2500 \mathrm{~g}$ dans 2 cas.

Trois nouveaux-nés n'ont pas eu besoin d'être transferés en néonatologie. Les six autres nouveaux-nés $(<35$ semaines de gestation) ont tous nécessité un traitement et la période néonatale a été différente pour chaque cas. Parmi les jumeaux nés vivants, un est décédé.

Dans trois cas l'insuffisance placentaire était la cause de la mort intra-utérine, dans trois autres cas c'était un syndrome de transfusion fœto-fœtale, dans un cas une défaillance cardiaque avec transfusion fœto-fœtale, mais dans deux cas la cause de la mort n'est pas claire.

On n'a pas observé de malformations chez les jumeaux morts in utéro.

Il n'y a eu qu'un seul accouchement spontané, les 8 autres $(89 \%)$ ont eu lieu par césarienne.

Le sex-ratio de tous les nouveaux-nés est de 10 garçons sur 7 filles, alors qu'il est de 3 garçons sur 5 filles pour les foetus morts in utéro, et que le sex ratio des survivants est de 7 garçons sur 2 filles. Dans 4 cas le deuxièm jumeau est mort in-utéro.

La nature des membranes est la suivante: dasn 5 cas il s'agissait de placenta monochorioniques-diamniotiques et, dans 3 cas, de placentas dichorioniques-diamniotiques. Dans ce cas, la présence de communications vasculaires signifiaient qu'il existait des conditions anatomiques pour au'existe un syndrome de transfusion fœto-fœtale.

Les symptomes de la gestose ont représenté les anomalies principales au cours de la grossesse comme il fallait s'y attendre.

Le fait que la mort fotale soit survenue quelque temps auparavant n'a été découvert au moment de l'accouchement que dans trois cas.

On n'a pas observé de complications secondaires dues à la mort fotale intra-utérine en ce qui concerne la morbidité maternelle etle post-partum.

Le taux de mortalité des jumeaux est 3 à 4 fois plus élevé que pour les nouveaux-nés uniques et la morbidité est également augmentée tout particulièrement en raison du fort pourcentage d'accouchements prématurés. En ce sens, le second jumeau est tout particulièrement à risque. Le taux de morts intra-utérines est également 2 à 3 fois plus élevé que pour les grossesses uniques [8).

L'incidence de $0,1 \%$ dans notre population étudiée en se référant à l'ensemble des naissances est compatible avec les autres auteurs.

Avec 33,1 ans, l'âge maternel moyen est nettement plus éléve que dans les autres études.

Les résultats de notre étude montrent que la mort intrautérine d'un jumeau n'expose pas en soi la mère à un risque accru.

Parmi les jumeaux survivants in utero, l'un est mort après l'accouchement $(11,1 \%)$; l'âge gestationnel de ce cas était de 25 semaines, le plus bas de notre étude.

Il n'y a pas de lésion entre la vitalité d'un nouveau-né suivant et l'intervalle entre la mort intra-utérine de l'autre jumeau et l'accouchement.

Avec $89 \%$, le taux élevé de césarienne comme méthode d'accouchement est frappent. L'incidence des césariennes est grandement fondée sur l'attitude obstétricale face aux présentations du siège: dans notre population, cette présentation anormale a été la seule indication dans ce cas. On comprend mieux la plus grande facilité à pratiquer une césarienne dans les cas où le diagnostic de mort fœtale intra-utérine est porté en urgence et lorsque d'autres facteurs de risque tel qu'un saignement vaginal abondant en même temps. Il n'y a pas eu de malformations dans notre étude ni chez les jumeaux décedés ni chez les survivants.

L'incidence de placentas monochoriaux dans notre étude est compatible avec ce qui est rapporté par les autres auteurs: 5 de nos 9 cas, 4 parmi eux avaient un syndrome de transfusion fœto-fœtale. Le receveur est mort in utéro dans 3 cas, le donneur dans 1 cas.

Les syndromes de transfusion rapportés ici étaient chroniques dans 3 cas et subchronique 1 fois. Une transfusion sanguine a été nécessaire à la période néonatale dans les deux cas chroniques chez lesquels le donneur a survécu (l'un des deux qui avait un taux initial particulièrement bas d'hémoglobine à 4,4\%). En se fondant sur les expériences publiées, le mode et le moment de la terminaison de la grossesse en cas de jumeau survivant sont déterminés avant tout par la maturité fœtale. Le type de placenta devrait également être pris en compte: sexes différents), on peut estimer en règle générale qu'il n'y a pas de risque fotal accru et que l'on peut attendre le déclenchement spontané du travail en surveillant le fœtus et les paramètres maternels.

Si l'one ne peut éliminer une grossesse monochoriale, il $\mathrm{y}$ a un risque accru pour le jumeau survivant du fait des shunts vasculaires qui peuvent entrainer la mort ou des lésions d'organes.

Nous proposons les points généraux suivants comme guides en cas de mort intra-utérine d'un fotus en cours d'une grossesse gemellaire:

Il n'y a pas pour la mère de risque accru en liaison directe, les paramètres adéquats devraient être surveillés 
régulièrement pour dépister toute perturbation de la coagulation. La mort intra-utérine d'un jumeau n'est pas une indication absolue d'interruption de la grossesse du survivant. Néanmoins, il faut effectuer une surveillance CTC et échographique afin de dépister les facteurs de risque qui en cas de placenta monochorial pourrait apparaître chez le survivant dans le cadre d'un syndrome de transfusion fœto-fœtale. Il s'agit du seul mode de surveillance du bien être du jumeau survivant et c'est justement l'état du jumeau en dehors de complications (hémorragies) qui peuvent survenir n'importe quand, qui détermine le moment et le mode d'accouchement.

Il faudrait toujours essayer d'obtenir la maturité pulmonaire fotale en atteignant un âge gestationnel approprié ou par induction. Une appréciation étroite de l'état maternel et de l'enfant survivant est nécessaire et la mère doit être hospitalisée pour celà. Dans l'idéal, il devrait être possible de réduire l'incidence des césariennes jusqu'au taux des grossesses gemellaires non compliquées.

Mots-clés: Grossesse gemellaire, mort intra-utérine d'un jumeau, mode d'accouchement, placentation, morbidité néonatale.

Acknowledgements: We are grateful to Prof. Dr. M. Vogel (Department for Paidopathology and Placentology at the Klinikum Charlottenburg) for the autopsy and placental findings.

\section{References}

[1] D’Alton ME, ER Newton, CL Cetrulo: Intrauterine fetal demise in multiple gestation. Acta Genet Med Gemellol 33 (1984) 4349

[2] Hagay ZJ, M Mazor, JR LeibermanN: Multiple pregnancy complicated by a single intrauterine fetal death. Obstet Gynecol 66 (1985) 837-838 (Letter)

[3] Hagay ZJ, M Mazor, JR LeibermanN: Management and Outcome of Multiple Pregnancies Complicated by the Antenatal Death of One Fetus. J Reprod Med 31 (1986) 717-720

[4] KINDRED JE: Twin pregnancies with one twin blighted: Reports of two cases with comparative study of cases in the literature. Am J Obstet Gynecol 48 (1944) 642-682

[5] Kloos K, M Vogel: Pathologie der Perinatalperiode. Georg Thieme Verlag Stuttgart 1974

[6] Litschgi M, D StuckI: Verlauf von Zwillingsschwangerschaften nach intrauterinem Fruchttod eines Föten. Z Geburtsh u Perinat 184 (1980) 227230

[7] Livnat EJ, L Burd, A Cadkin, P Keh, AB Ward: Fetus Papyraceus in Twin Pregnancy. Obstet Gynecol 51 Suppl (1978) 415-455

[8] LUMME R, S SAARIKovSKI: Antepartal fetal death of one twin. Int J Gynecol Obstet 25 (1987) $331-336$
[9] OtTolenghi-PetRi GF: Sopra un rarissiomo caso di gravidanza gemellare con un feto papiraceo e con inserzione velamentosa del funicolo del feto vivo. Ann Ost Gin Med Perin XCIII (1972) 173199

[10] Pritchard JA: Fetal death in utero. Obstet Gynecol 14 (1959) 573-580

[11] RIEHN A: Über das Risiko nach intrauterinem Fruchttod eines Feten bei Zwillingsschwangerschaft. Zbl Gynäkol 104 (1982) 1530-1536

[12] Romero R, T Duffy, RL Berkowitz, E Chang, JC HoBBINS: Prolongation of a preterm pregnancy complicated by death of a single twin and disseminated intravascular coagulation. $\mathrm{N}$ Engl J Med 310 (1984) $772-774$

[13] Skelly H, M Martivate, R Norman, G Kenoyer, R MARTIN: Consumptive coagulopathy following fetal death in a triplet pregnancy. Am J Obstet Gynecol 142 (1982) 595-596

Received May 5, 1988. Accepted September 10, 1988.

Dr. Jens Wessel

Universitätsfrauenklinik Charlottenburg

Pulsstr. 4-14

D-1000 Berlin 19, West Germany 